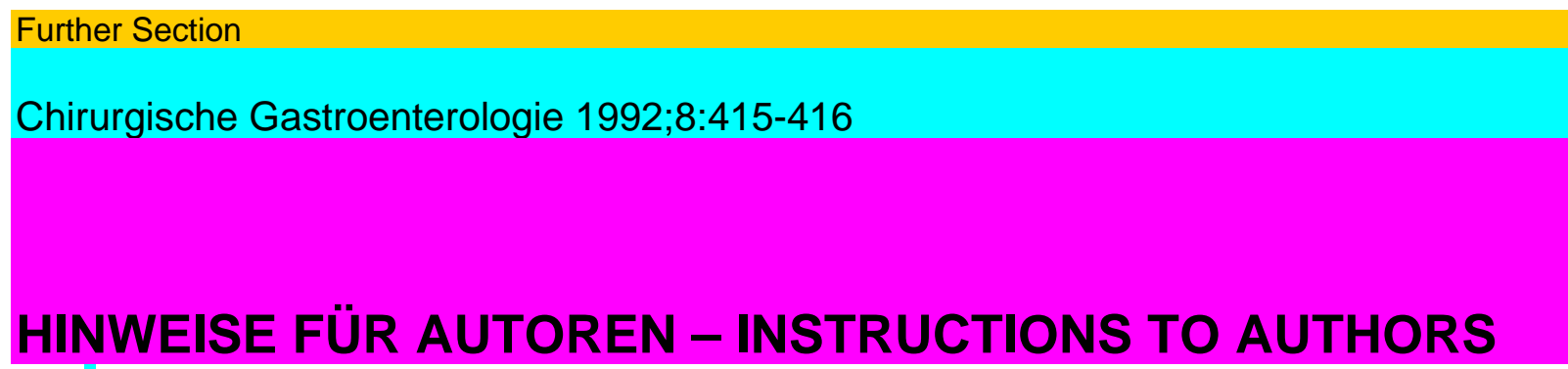

1. Allgemeines, Verlagsrecht

Bitte senden Sie Îhr Manuskript direkt an die Redaktion z. Hd. Frau Marlene Mörlins, Rehwinkel 13, W-3250 Hameln 5, Tel. 05151/61375, Fax 05151/Ó7243.

Das Manuskript soil in satzreifem Zustand in dreifacher Ausferti-gung eingereicht werden. Die Entscheidung über die Aufnahme erfolgt aufgrund mehrerer Gutachten. Eine Kopie des Manuskripts soil grundsätzlich beim Autor verbleiben.

Typographische Gestaltung und redaktionelle Bearbeitung sind dem Verlag vorbehalten. Die Arbeit darf nicht gleichzeitig bei einer anderen Publikation eingereicht sein. Es ist Sache des Autors, die Nachdruckerlaubnis für Abbildungen, Tabellen usw. aus anderen Publikationen zu beschaf-fen. Mit der Annahme des Manuskriptes zur Publikation gehen alle Rechte auf den Verlag über. Ohne schriftliche Genehmigung des Verlages dürfen diese Publikationen oder Teile daraus nicht in an-dere Sprachen übersetzt oder in irgendeiner Form mit mechani-schen oder elektronischen Mitteln (einschließlich Fotokopie, Ton-aufnahme und Mikrokopie) reproduziert oder auf einem Datenträ-ger oder einem Computersystem gespeichert werden. Geschützte Markennamen müssen mit einem hochgestellten $\beta$ bezeichnet werden. Die Verantwortung für die korrekte Befolgung dieser Vorschrift liegt ausschließlich beim Autor.

1. General Remarks - Publishing Laws

Please send your manuscript directly to the editorial office, Attn.: Mrs. Marlene Mörlins, Rehwinkel 13, W-3250 Hameln 5 (FRG). Tel. 05151/61375, Fax 05151/67243.

The manuscript should be submitted in triplicate, ready for printing. Acceptance of a manuscript is based on the evaluation by several referees. The author should always keep a copy of the manuscript. The publisher reserves the right to edit the manuscript and decide on the layout. The manuscript is received with the understanding that it is not under simultaneous consideration for publication elsewhere. It is the authors responsibility to obtain permission to reproduce illustrations, tables etc. from other publishers. Once the manuscript is accepted for publication, all the rights will be retained by the publisher. The publication, or parts of it, may not be translated into other languages, or reproduced by any mechanical or electronic means (including photocopying, recording and microcopying), or stored in a retrieval system without the publisher's written permission.

Registered trade names must be marked with the superscript registration symbol ${ }^{\circledR}$. It is the sole responsibility of the author to ensure that this rule is followed properly.

\title{
2. Manuskripte
}

Diese sollen in 1/1/2zeiligem Abstand geschrieben sein, links und rechts einen angemessenen breiten Rand aufweisen und (ein-schließlich Titelseite und Literaturverzeichnis) kontinuierlich durchnumeriert sein. Folgende Gliederung wird empfohien:

Titelseite mit Titel und Kurztitel der Arbeit in Deutsch und Eng-lisch; Autorenangabe; Institutsangabe in der Landessprache der Autoren. 
Zusammenfassung und Schlüsselwörter in Deutsch und Eng-lisch. Zusammenfassungen sollen 20 Schreibmaschinenzeilen nicht überschreiten. In die Zusammenfassung gehören keine Literaturzi-tate, Tabellen, Abbildungen und Abbildungs- und Tabellenhinweise sowie allgemein gehaltene Aussagen. $\mathrm{Zu}$ einer Arbeit gehören 3-5 Schlüsselwörter.

Textseiten der Arbeit mit Gliederung in Einleitung, Material und Methoden (oder: Patientengut und Methoden), Ergebnisse, Dis-kussionen. Fußnoten (gegebenenfalls numeriert) am unteren Rand jeder Textseite.

Abkürzungen bitte möglichst sparsam verwenden. Bei speziellen Abkürzungen jeweils beim ersten Auftreten das Wort ausschreiben und die später verwendete Abkürzung in Klammern folgen lassen: z.B. Adenosin-Nonophosphat (AMP).

Danksagungen sollten unmittelbar dem Text folgen und dem Literaturverzeichnis vorangestellt sein.

Das Literaturverzeichnis soil nur die im Text zitierten Publikationen enthalten. Die Literatur ist entsprechend der Reihenfolge im Text zu numerieren. Es sollen nur Arbeiten, die entweder publi-ziert oder zur Publikation angenommen sind, zitiert werden. Der Passus «in Vorbereitung» oder «persönliche Mitteilung» ist zu ver-meiden.

Literaturzitate werden mit oder ohne Angabe des Erstautors in den Text eingefügt, z.B. [1] oder

Romberg [1] oder Romberg et al. [1].

Zur Abfassung von Literaturzitaten gelten folgende Beispiele:

1. Manuscripts

The manuscripts should be typed in a spacing of $1 \frac{1}{2}$ lines with adequately wide margins (left and right). They should be consecutively numbered (including front page and reference list). We recommend the following division:

Front page with title and short title in German and English; author's name, institute name in the native language of the authors.

Summary and Key Words in German and English. Summaries should not exceed 20 typewritten lines. Summaries should not include any references, tables, figures, references to figures and tables and general statements. Each article should have 3-5 key words.

Text pages should be divided into introduction, materials and methods (optionally patients and methods), results, discussion.

Footnotes (with numbers) are placed at the bottom of each page of the text.

Please use abbreviations as economically as possible. Special abbreviations should be written in full when first mentioned followed by the abbreviation in parenthesis, e.g. adenosine-

monophosphate (AMP). Acknowledgements should be placed directly after the text, and before the list of references.

The list of references should include only the publications cited in the text. The references should be numbered according to their order of appearance in the text. It is recommended to quote only articles which have been either published already or accepted for publication.

Please avoid passages like 'in preparation' or 'personal communication'. Quotes from references are inserted into the text with or without the name of the first author, e.g. [1], or Romberg [1] or Romberg et al. [1]. For references the following examples are compulsory:

Outline of a magazine reference:

Kauffmann HF, van der Heide S, Beaumont F, Blok H, de Vries K: Class-specific antibody determination against Aspergillus fumi-gatus by means of the enzyme-linked immunosorbent assay. III.

(C) 1992 S. KargerGmbH. Freiburg 
Darstellungsschema einer Zeitschrifienreferenz:

Kauffmann HF, van der Heide S, Beaumont F, Blok H, de Vries K: Class-specific antibody determination against Aspergillus fumi-gatus by means of the enzyme-linked immunosorbent assay. III. Comparative study: IgG, IgA, IgM ELISA titers, percipitating antibodies and IgE binding after fractionation of the antigen. Int Arch Allergy Appl Immunol 1986;80:300-306. Darstellungsschema einer Buchreferenz:

Hardy WD Jr, Essex M: FeLV-induced feline acquired immune deficiency syndrome: A model for human AIDS, in Klein E (ed): Acquired Immunodeficiency Syndrome. Prog Allergy. Basel, Kar-ger, 1986, vol 37, pp 353-376.

Die Zahl von Abbildungen und Tabellen soil niedrig gehalten werden und darauf abzielen, den Text zu erklären. Abbildungen werden mit (Abb. 1), Tabellen mit (Tab. 1) in den Text eingefügt. Bereits im Text genannte Zahlen bedürfen keiner Wiederholung in einer Tabelle. Umgekehrt brauchen die in Tabellen zusammenge-stellten Zahlen nicht im Text wiederholt zu werden. Farbabbildun-gen können angenommen werden, bedürfen aber eines Reprodukti-ons- und Druckkostenzuschusses, den der Autor zu tragen hat. Abbildungsvorlagen sind dreifach als Papierabzüge einzureichen. Vorlagen nicht aufkleben, lochen oder mit Büroklammern anhef-ten; auf der Rückseite den Namen des Autors, den Titel des Bei-trags, die Angabe, wo «oben» ist, sowie die Bildnummer angeben. Alle Abbildungen und Tabellen sind mit einer Legende zu verse-hen. Alle Legenden einer Arbeit werden auf einer gesonderten Sei-te zusammengestellt. Die Legenden sind kurz und präzise zu halten und sollen die Abbildungen bzw. Tabellen vollständig erklären. Die Interpretation der Daten erfolgt nicht in der Legende, sondern ausschließlich im Text.

Autorenadresse

Postanschrift des Autors am Schluß der Arbeit vollständig angeben.

3. Umfang von Manuskripten

Originalarbeiten (Gliederung s.o.) sollen 10 Textseiten nicht über-schreiten.

Kurzmitteilungen folgen der Gliederung von Originalarbeiten und sollen 5 Textseiten, 5-10

Literaturhinweise und maximal 1 Abbil-dung (oder wahlweise 2 Abbildungen oder Tabellen) nicht über-schreiten. Schwerpunkte von Kurzmitteilungen sollen neue Ergeb-nisse wissenschaftlicher Arbeiten, auch in Form sogenannter vor-läufiger Mitteilungen, und auch neue Studienansätze - experimen-tell oder klinisch - sein. Verlag und Schriftleitung wollen erreichen, daß solche Arbeiten innerhalb kürzester Zeit publiziert werden. Selbstverständlich bleibt es dem Autor überlassen, zu einem späteren Zeitpunkt eine ausführliche Fassung einzureichen. Über-sichtsarbeiten folgen nicht der Gliederung von Originalarbeiten. Titelseite, Zusammenfassung und Literaturverzeichnis (s.o.) sind jedoch erforderlich.

4. Kosten und Sonderdrucke

Übersteigen die Kosten der Autorkorrektur 10\% der Satzkosten, müssen diese dem Autor in Rechnung gestellt werden. Dem Autor stehen 40 Gratissonderdrucke seiner Arbeit zu.

Comparative study: IgG, IgA, IgM ELISA titers, precipitating antibodies and IgE binding after fractionation of the antigen. Int Arch Allergy Appl Immunol 1986;80:300-306. Outline of a book reference:

Hardy WD Jr, Essex M: FeLV-induced feline acquired immune deficiency syndrome: A model for human AIDS, in Klein E (ed): Acquired Immunodeficiency Syndrome. Prog Allergy. Basel, Kar-ger, 1986, vol 37, pp 353-376.

The number of figures and tables should be limited and aim to illustrate the text. Figures are listed in the text as (fig. 1), tables as (table 1). Figures already mentioned in the text need not be 
repeated in a table. Accordingly, numbers used in tables need not be repeated in the text. Figures in color may be accepted, provided the author is prepared to defray the costs involved. Do not fasten original figures with glue or paper clips or punch holes in them. Please state on the back the autor's name, the title of the article, the 'top' instruction and the number of the figure. All figures and tables must include a legend. All legends should be listed together on a separate page. Legends should be kept short and precise and should illustrate the figures and tables exhaustively. The data should not be interpreted in the legend but exclusively in the text. Author's address Please give the author's full address at the bottom of the article.

3. Volume of Manuscripts

Original papers (framework see above) should not exceed 10 text pages.

Short communications adhere to the framework of original papers and should not exceed 5 text pages, 5-10 references and a maximum of 1 figure and 1 table (optionally either 2 figures or tables). Short communications should focus on the result of cientific studies, also in the form of so called provisional reports as well as new scientific approaches either experimental or clinical. It is the publisher's and the editorial staff's aim to manage the publishing of such articles within the shortest period of time possible. It goes without saying that the author is at liberty to hand in a complete version at a later date.

Review articles do not adhere to the framework of original papers, the title page, a summary and a list of references (see above) are, however, compulsory.

4. Costs of Reprints

The author will be charged for corrections to the galley proofs entailing expenses in excess of $10 \%$ of the original typesetting costs. The author is entitled to 40 free reprints of his or her article.

416

Hinweise für Autoren — Instructions to Authors

Zerlegbare Scheren für die Laparoskopie -

eine neue Instrumentengeneration von KARL STORZ

Mitden neuen,zerlegbaren Scheren stellt KARL STORZ eine neue Generation laparoskopischer In-strumente vor - Instrumente, die bestmöglichen Schutz vor Infekti-onsgefahren und optimale Funk-tionsfähigkeit bei einer deutlich verbesserten Kosten-Nutzen-Relation bieten. Möglich wurde dies durch ein vollständig neues, modulares Konstruktionsprinzip, bei dem jede Schere aus 3 aus-wechselbaren Grundelementen zusammengesetzt ist. Dadurch können die Instrumente ohne großen Aufwand zerlegt und mit bisher nicht gekannterGründlich-keit gereinigt und autoklaviert werden - ohne Schmutzfallen in unzugänglichen Ecken und Hohlräumen.Auch die mitzunehmen-dem Gebrauch nachlassende Schneideleistung von Scheren braucht nicht längerein Problem zu sein. Mit wenigen Handgriffen können die Scherenteile jetzt ge-gen einen fabrikneuen Einschub ausgetauscht werden. Dies führt nicht zuletzt auch zu einer deutli-chen Kostensenkung, da nurTeile der Schere und nicht das Ge-samtinstrument ausgetauscht werden müssen.

Bitte überzeugen Sie sich selbst vonderQualitätunsererProdukte und fordern Sie eine unverbindli-che Demonstration durch unse-ren Außendienst an.

KARL STORZ GMBH \& CO.

Mittelstr. 8, Postfach 230

D-7200 Tuttlingen/Germa $\pi$ y 
Cable: Endoskopie

Phone: (07461) 7080, Telex: 762656 storzd

Teletex: 746118, Telefax: (0 74 61) 708105

KARL STORZ Endoscopy - America, Inc. 10111 W. Jefferson Boulevard, Culver City,

California 90232-3578, Phone: (213) 5581500, Telex: 910-340-6372 k storz culv. Telefax: 213 2802504

KARL STORZ Endoscopia Latino-America

815 N.W. 57 AV, Suite No. 342

Miami, Florida 33126

Phone: KSLA (305) $262-8980$

Telex: 510601 6506, Telefax: (305) 262-8986

Ich möchte weitere Informationen.

Bitte senden Sie mir den Katalog

Endoskopische Chirurgie

STORZ

KARL STORZ- ENDOSKOPE

Q-

11

$\mathrm{J}$ 